\title{
ANALISIS DAMPAK FUNGSIONAL KEBERADAAN HUTAN MANGROVE DI KABUPATEN TUBAN
}

\author{
Yuyun Suprapti, Achmad Sudianto \\ Program Studi Ilmu Perikanan Universitas PGRI Ronggolawe Tuban \\ Email : yuyunsuprapti80@gmail.com, achmadsudianto@yahoo.co.id
}

\begin{abstract}
Abstrak
Pengikisan pantai bertambah parah seiring dengan bertambahnya bermacam-macam aktivitas warga dan keberadaan Industri di beberapa wilayah sisi utara Kabupaten Tuban. Pada sektor budidaya perikanan banyak para pelaku usaha budidaya yang menutup tambaknya karena pohon bakau yang berfungsi sebagai penangkal arus air laut hilang ditebang secara liar. Penelitian ini bertujuan untuk menganalisis dampak fungsional tentang keberadaan tanaman mangrove, terhadap abrasi yang terjadi di sepanjang sisi utara Kabupaten Tuban. Metode yang digunakan adalah survey dengan kuisioner, metode Sistem Informasi Geografis (GIS) digunakan untuk membaca peta topografi tentang pergeseran garis pantai. Analisis data menggunakan semantic diferensial. Sumber data yang dikumpulkan dalam penelitian ini adalah data primer dan sekunder. Pengumpulan data primer diperoleh langsung didaerah penelitian dengan cara wawancara menggunakan kuisioner dan observasi (pengamatan). Observasi dimaksudkan untuk memperoleh gambaran tentang lokasi, keadaan lingkungan kawasan hutan mangrove, wawancara dilakukan untuk mendapatkan keterangan dan informasi secara lisan dari responden mengenai karakteristik, pola pemanfaatan, dan peran serta masyarakat dalam pengelolaan potensi hutan mangrove sesuai dengan pertanyaan yang diajukan. Data sekunder berupa data kondisi hutan mangrove, keadaan demografi dan geografi, serta keberadaan sarana dan prasarana yang terkait dengan pengelolaan tanaman mangrove yang diperoleh dari lembaga dan instansi yang terkait. Manfaat dari penanaman kembali mangrove-magrove adalah untuk memperbaiki ekosistem yang sudah rusak, memberikan dampak positif bagi masyarakat sekitar lokasi konservasi pada khususnya dan masyarakat Tuban pada umumnya. Dampak positif yang timbul secara fungsional yaitu menjaga garis pantai, menjaga ekosistem pantai yang merupakan tempat hidup berbagai macam biota laut. Hasil kuisioner dampak keberadaan tanaman mangrove secara fungsional menunjukkan rata-rata 6,05 artinya berdampak positif bagi masyarakat dan lingkungan. Maka dapat disimpulkan bahwa perlu dilakukan sosialisasi/penyuluhan, pembinaan dalam pemanfaatan tanaman mangrove secara serius dengan dukungan dari pemerintah daerah melalui Dinas yang terkait.
\end{abstract}

Kata kunci :Abrasi, Mangrove, Dampak Fungsional, penyuluhan.

\begin{abstract}
The erosion of the coast has worsened along with the increase in various activities of citizens and the existence of the Industry in some areas of the northern side of Tuban Regency. In the aquaculture sector, many aquaculture businessmen closed their ponds because mangroves that functioned as an antidote to the flow of lost sea water were felled wildly. This study aims to analyze the functional impact of the presence of mangroves, on abrasion that occurs along the northern side of Tuban Regency. The method used is a questionnaire survey, the Geographic Information System (GIS) method is used to read topographic maps about shoreline shifts. Data analysis uses semantic differential. Sources of data collected in this study are primary and secondary data. Primary data collection was obtained directly in the study area by means of interviews using questionnaires and observations. Observations are intended to obtain an overview of the location, environmental conditions of the mangrove forest area, interviews are conducted to obtain information and information orally from respondents regarding the characteristics, patterns of utilization, and the role of the community in managing the potential of mangrove forests according to the questions asked. Secondary data in the form of data on the condition of mangrove forests, demographic and geographic conditions, and the presence of facilities and infrastructure related to the management of mangroves obtained from relevant institutions and agencies. The benefits of replanting mangroves are to improve damaged ecosystems, have a positive impact on communities around conservation areas in particular and the people of Tuban in general. The positive impacts that arise functionally are guarding the coastline, safeguarding the coastal ecosystem which is the place of life for various kinds of marine biota. The results of the questionnaire on the impact of functional mangroves showing an average of 6.05 means that they have a positive impact on the community and the environment. So it can be concluded that it is necessary to conduct socialization / counseling, fostering the use of mangrove plants seriously with support from the local government through the relevant agency.
\end{abstract}

Keywords: Abrasion, Mangrove, Functional Impact, Counseling. 


\section{PENDAHULUAN}

Kerusakan daerah pesisir akibat Abrasi (pengikisan pantai) yang ada di sisi utara Kabupaten Tuban dari waktu ke waktu terus meningkat. Kondisi seperti ini apabila tidak segera mendapatkan penanganan serius, maka dalam jangka waktu sepuluh tahun ke depan berakibat terancamnya kerusakan yang lebih serius. Khususnya keberadaan jalur pantura yang merupakan akses dan sarana transportasi darat utama dapat berpotensi menimbulkan longsor karena abrasi (Komunikasi personal: Mansyur, 2014).

Dampak dari kerusakan ini membuat keresahan warga yang berdomisili disekitar pantai utara Kabupaten Tuban, apabila kondisi ini dibiarkan tanpa adanya penanganan. Abrasi sudah terjadi selama puluhan tahun namun hingga saat ini belum ada penanganan yang serius oleh Pihak Pemerintah Daerah. Pengikisan pantai yang sudah terjadi puluhan tahun yang lalu, keadaan kian lama kian parah, seiring dengan bertambahnya bermacammacam aktifitas warga.

Salah satu aktivitas warga pesisir pantai yang banyak ditemui diantaranya kegiatan pembudidayaan ikan/udang khususnya tambak. Pengusaha tambak yang berada di pinggir pantai banyak yang gulung tikar, sebab abrasi pantai yang kian tahun semakin melebar, tambak-tambak mereka tergerus gelombang ombak tanpa penangkal sama sekali. Bibir pantai telah terkikis hingga daratan pinggir pantai sepanjang sekitar 50 meter dan menghancurkan ratusan hektar lahan tambak. Hal ini terjadi karena pohon bakau yang berfungsi sebagai penangkal arus air laut, hilang karena penebangan liar.

Pohon bakau yang selama ini ditanam oleh Dinas Kehutanan dan Badan Lingkungan Hidup Pemerintah Kabupaten Tuban juga sudah banyak yang mengalami kerusakan karena tidak mampu menahan gelombang air laut, selain itu juga karena kurangnya perawatan. Sedangkan pohon mangrove yang sudah menginjak masa pengembangan juga banyak ditebang oleh oknum yang tidak bertanggung jawab dan tanpa ada sanksi apapun.

Salah satu upaya yang harus dilakukan adalah dengan melakukan reboisasi/penanaman kembali tanaman mangrove disepanjang pantai utara Tuban. Adapun manfaat dari penanaman kembali mangrove-magrove adalah untuk memperbaiki ekosistem yang sudah rusak, memberikan dampak positif bagi masyarakat sekitar lokasi konservasi pada khususnya dan masyarakat Tuban pada umumnya. Dampak positif yang timbul secara fungsional yaitu menjaga garis pantai, menjaga ekosistem pantai yang 
merupakan tempat hidup berbagai macam biota laut.

Berdasarkan uraian kondisi lingkungan alami selayaknya mendukung kelestarian hutan mangrove. Namun demikian, akibat pemanfaatan yang tidak terkendali dan sudah berlangsung lama, mengakibatkan terjadinya kerusakan hutan mangrove, sehingga menurunkan fungsionalnya sebagai pelindung pantai akibat abrasi, maka rumusan masalah yang akan diteliti adalah:

1. Bagaimana dampak fungsional abrasi?

2. Bagaimana pengelolaan konservasi mangrove hingga mampu mengurangi abrasi?

Berdasarkan rumusan masalah, maka tujuan penelitian adalah:

1. Mengetahui pengaruh dampak fungsional abrasi secara langsung;

2. Mengetahui pengelolaan konservasi mangrove sehingga proses abrasi dapat diketahui.

\section{METODE PENELITIAN}

Metode yang digunakan dalam penelitian ini adalah metode survey yaitu dengan pengamatan langsung dilapangan. Penelitian survey adalah penelitian yang mengambil sampel dari satu populasi dan menggunakan kuisioner sebagai alat pengumpulan data yang pokok Tabel 1. Hasil kuisioner Dampak Fungsional
(Singarimbun dan Sofian Effendi, 1989). Analisis data yang digunakan dalam penelitian ini yaitu Semantik Diferensial (Osgood Scale/Skala Osgood). Dikembangkan oleh Charles E.Osgood, G.J.Suci, dan P.H Tannembaum (1975). Dalam teknik ini responden tidak diminta untuk memberikan respon setuju atau tidak setuju, akan tetapi diminta untuk langsung memberikan bobot penilaian mereka terhadap suatu stimulus.

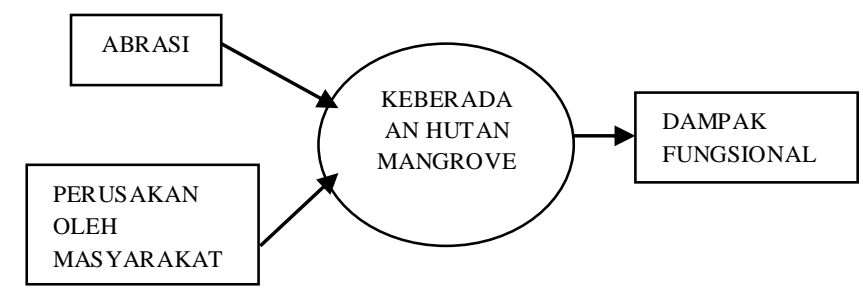

\section{HASIL DAN PEMBAHASAN}

Hasil kuisioner abrasi yang menimbulkan dampak fungsional antara lain, abrasi pantai terjadi karena alam, garis pantai bergeser hingga $200 \mathrm{~m}$, intrusi air laut ke darat, polusi udara terganggu, kerusakan mangrove, rusaknya ekosistem biota laut, hilangnya populasi burung langka, salinitas tambak meningkat, meningkatnya frekuensi dan intensitas banjir, sampah RT dan limbah industry menjadi penyebab abrasi, terganggunya obyek wisata pantai, tidak adanya tempat obyek penelitian, pendidikan dan pengembangan ilmu pengetahuan. Berikut tabel dampak fungsional hasil kuisioner. 


\begin{tabular}{|c|c|c|c|c|c|c|c|c|c|}
\hline No & Pertanyaan & 7 & 6 & 5 & 4 & 3 & 2 & 1 & $\begin{array}{l}\text { Rata- } \\
\text { Rata }\end{array}$ \\
\hline 1 & Abrasi pantai terjadi karena alam & 2 & 30 & 60 & 8 & 0 & 0 & 0 & 5,26 \\
\hline 2 & Garis pantai bergeser hingga $200 \mathrm{~m}$ & 38 & 44 & 13 & 4 & 1 & 0 & 0 & 6,14 \\
\hline 3 & Intrusi air laut ke darat & 16 & 52 & 26 & 4 & 1 & 1 & 0 & 5,75 \\
\hline 4 & Polusi udara terganggu & 10 & 24 & 52 & 11 & 3 & 0 & 0 & 5,27 \\
\hline 5 & Kerusakan mangrove & 50 & 23 & 24 & 2 & 1 & 0 & 0 & 6,19 \\
\hline 6 & Rusaknya ekosistem biota laut & 85 & 11 & 3 & 1 & 0 & 0 & 0 & 6,8 \\
\hline 7 & Hilangnya populasi burung langka & 80 & 18 & 1 & 1 & 0 & 0 & 0 & 6,8 \\
\hline 8 & Salinitas tambak meningkat & 15 & 44 & 29 & 11 & 0 & 1 & 0 & 5,6 \\
\hline 9 & $\begin{array}{l}\text { Meningkatnya frekuensi dan } \\
\text { intensitas banjir }\end{array}$ & 10 & 35 & 46 & 8 & 1 & 0 & 0 & 5,45 \\
\hline 10 & $\begin{array}{l}\text { Sampah RT dan limbah industry } \\
\text { menjadi penyebab abrasi }\end{array}$ & 37 & 37 & 19 & 5 & 2 & 0 & 0 & 6,02 \\
\hline 11 & Terganggunya obyek wisata pantai & 71 & 24 & 4 & 1 & 0 & 0 & 0 & 6,65 \\
\hline 12 & $\begin{array}{l}\text { Tidak adanya tempat obyek } \\
\text { penelitian, pendidikan dan } \\
\text { pengembangan ilmu pengetahuan }\end{array}$ & 79 & 16 & 4 & 1 & 0 & 0 & 0 & 6,73 \\
\hline & & $\begin{array}{c}487 \\
(69,6 \%)\end{array}$ & $\begin{array}{c}358 \\
(59,7 \%)\end{array}$ & $\begin{array}{c}281 \\
(56,2 \%)\end{array}$ & $\begin{array}{c}57 \\
(14,2 \%)\end{array}$ & $\begin{array}{c}9 \\
(3 \%)\end{array}$ & $\begin{array}{c}2 \\
(1 \%)\end{array}$ & 0 & 6,055 \\
\hline
\end{tabular}

Dari data 100 responden hasil kuisioner dampak fungsional bahwa abrasi pantai terjadi karena alam. Responden menjawab 7 sebanyak 2 responden, menjawab 6 sebanyak 30 responden, menjawab 5 sebanyak 60 responden, menjawab 4 sebanyak 8 responden, untuk responden yang menjawab 3, 2, 1 tidak ada. Rata-rata jawaban dari pertanyaan abrasi pantai terjadi karena alam 5,26. Jawaban cenderung ke angka 4,5,6 artinya bahwa menurut sebagian penduduk sekitar lokasi konservasi bahwa penyebab utama abrasi adalah alam meskipun manusia sebagai pemicu utama.

Pergeseran garis pantai yang terjadi di pantai Tuban akibat dampak abrasi, masih menjadi pertanyaan yaitu sejauh berapa meter hilangnya garis pantai. Hasil kuisioner dari 100 responden yang menyatakan garis pantai bergeser hingga $200 \mathrm{~m}$, responden menjawab 7 sebanyak 38 responden, menjawab 6 sebanyak 44 responden, menjawab 5 sebanyak 13 responden, menjawab 4 sebanyak 4 responden, menjawab 3 sebanyak 1 responden, menjawab 2 dan 1 tidak ada. Rata-rata jawaban 6,14. Jawaban cenderung ke angka 5, 6, 7, yang artinya bahwa menurut responden dengan kriteria yang ditetapkan peneliti, garis pantai bergeser mencapai $200 \mathrm{~m}$.

Dari data 100 responden menyatakan abrasi menyebabkan intrusi air laut ke darat, yang menjawab 7 sebanyak 16 responden, menjawab 6 
sebanyak 52 responden, menjawab 5 sebanyak 26 responden, menjawab 4 sebanyak 4 responden, menjawab 3 dan 2 sebanyak 1 responden, menjawab 1 tidak ada. Rata-rata jawaban dari pertanyaan adanya abrasi menyebabkan intrusi air laut ke darat 5,75, jawaban cenderung ke angka 5, 6, 7 artinya bahwa salah satu dampak abrasi yaitu intrusi air laut ke darat.

Kerusakan mangrove yang terjadi di Tuban beberapa tahun yang lalu, menyebabkan dampak negative diantaranya polusi udara terganggu. Hasil kuisioner responden yang menjawab 7 sebanyak 10 responden, menjawab 6 sebanyak 24 responden, menjawab 5 sebanyak 52 responden, menjawab 4 sebanyak 11 responden, menjawab 3 sebanyak 3 responden, menjawab 2 dan 1 tidak ada. Rata-rata jawaban untuk pertanyaanb adanya kerusakan hutan mangrove menyebabkan polusi udara terganggu 5,27, jawaban cenderung di angka 4, 5, 6, 7 artinya bahwa hutan mangrove mempunyai peran penting dalam menyerap zat-zat berbahaya, dimana mangrove di Tuban berada di sepanjang jalur Pantura dan banyak berdiri pabrik-pabrik besar.

Kerusakan mangrove menjadi faktor utama terjadinya abrasi. Dari 100 responden hasil kuisioner yang menjawab 7 sebanyak 50 responden, menjawab 6 sebanyak 23 responden, menjawab 5 sebanyak 24 responden, menjawab 4 sebanyak 2 responden, menjawab 3 sebanyak 1 responden, menjawab 2 dan 1 tidak ada. Rata-rata jawaban dari pertanyaan kerusakan mangrove menjadi pemicu adanya abrasi 6,19 , jawaban cenderung ke angka 5, 6, 7 yang berarti bahwa hubungan antara mangrove dan abrasi merupakan sesuatu yang saling berkaitan. Jika pengelolaan hutan mangrove semakin baik, maka kondisi abrasi akan semakin baik pula.

Rusaknya ekosistem biota laut merupakan salah satu dampak abrasi. Hasil kuisioner 100 responden yang menjawab 7 dari pertanyaan ini sebanyak 85 responden, menjawab 6 sebanyak 11 responden, menjawab 5 sebanyak 3 responden, menjawab 4 sebanyak 1 responden, menjawab 3, 2, 1 tidak ada. Rata-rata jawaban 6,8, jawaban cenderung ke angka $5,6,7$, artinya bahwa rusaknya mangrove berpengaruh pada punahnya beragam jenis fauna laut, karena mangrove sebagai penyedia makanan bagi ikan serta burung dan serangga yang tengah bermigrasi.

Burung langka seperti blekok saat ini jarang kita jumpai, penyebab berkurangnya habitat burung ini salah satunya karena kerusakan mangrove. Dari 100 responden hasil kuisioner yang menjawab 7 sebanyak 80 responden, menjawab 6 sebanyak 18 responden, menjawab 5 dan 4 sebanyak responden, 
menjawab 3, 2, 1 tidak ada. Rata-rata jawaban 6,8, jawaban terbanyak di angka 7, artinya bahwa keberadaan mangrove berpengaruh pada habitat burung-burung langka serta salah satu cara mengembalikan habitatnya.

Dari data 100 responden hasil kuisioner yang menyatakan bahwa adanya abrasi dan kerusakan mangrove berdampak negative pada salinitas tambak meningkat. Responden yang menjawab 7 sebanyak 15 responden, menjawab 6 sebanyak 44 responden, menjawab 5 sebanyak 29 responden, menjawab 4 sebanyak 11 responden, menjawab 3 tidak ada, menjawab 2 sebanyak 1, menjawab 1 tidak ada. Rata-rata jawaban dari pertanyaan adanya abrasi menyebabkan salinitas tambak meningkat 5,6, jawaban cenderung ke angka 5, 6, 7 .

Hasil kuisioner 100 responden yang menjawab pertanyaan pengaruh abrasi dan kerusakan mangrove menyebabkan meningkatnya frekuensi dan intensitas banjir. Responden menjawab 7 sebanyak 10 responden, menjawab 6 sebanyak 35 responden, menjawab 5 sebanyak 46 responden, menjawab 4 sebanyak 8 responden, menjawab 3 sebanyak 1 responden, menjawab 2 dan 1 tidak ada. Rata-rata jawaban dari pertanyaan di atas 5,45. Jawaban cenderung ke angka 5, 6, 7 ( terbanyak jawaban memilih angka 5 sebanyak 46 responden).

Sampah yang berasal dari rumah tangga dan limbah industry salah satu faktor penyebab abrasi. Hasil kuisioner data 100 responden yang menjawab 7 sebanyak 37 responden, menjawab 6 sebanyak 37 responden, menjawab 5 sebanyak 19 responden, menjawab 4 sebanyak 5 responden, menjawab 3 sebanyak 2 responden, menjawab 2 dan 1 tidak ada. Rata-rata jawaban untuk pertanyaan diatas 6,02. Jawaban cenderung ke angka 5, 6, 7 (responden menjawab 6 dan 7 masing-masing 37 responden).

Obyek wisata pantai merupakan sarana wisata dan rekreasi yang sering di datangi pengunjung dengan alasan gratis. Abrasi merupakan salah satu penyebab rusaknya tempat wisata pantai. Dari hasil kuisioner 100 responden yang menjawab 7 sebanyak 71 responden, menjawab 6 sebanyak 24 responden, menjawab 5 sebanyak 4 responden, menjawab 4 sebanyak 1 responden, menjawab 3, 2, 1 tidak ada. Rata-rata jawaban 6,65 , jawaban cenderung ke angka 6 dan 7 (responden memilih 7 sebanyak 71) artinya bahwa abrasi berdampak negative terhadap terganggunya obyek wisata pantai.

Kerusakan mangrove yang terjadi karena alam dan manusia sebagai pemicu cepatkan kerusakan yang menimbulkan 
dampak abrasi, maka area yang terkena abrasi tidak bisa difungsikan sebagai tempat obyek penelitian, pendidikan dan pengembangan ilmu pengetahuan. Dari data 100 responden hasil kuisioner, responden menjawab 7 sebanyak 79, menjawab 6 sebanyak 16 responden, menjawab 5 sebanyak 4 responden, menjawab 4 sebanyak 1 responden, menjawab 3, 2, 1 tidak ada. Rata-rata jawaban untuk pertanyaan ini 6,055. Jawaban cenderung ke angka 6 dan 7 (responden menjawab 7 sebanyak 79 responden dari 100 responden), artinya bahwa abrasi yang terjadi di pantai Tuban menganggu aktifitas penduduk, sehingga area pesisir yang seharusnya bisa dimanfaatkan tidak bisa di fungsikan sebagai tempat kegiatan.

Hasil kuisioner abrasi yang menimbulkan dampak fungsional antara lain, abrasi pantai terjadi karena alam, garis pantai bergeser hingga $200 \mathrm{~m}$, instrusi air laut ke darat, polusi udara terganggu, kerusakan mangrove, rusaknya ekosistem biota laut, hilangnya populasi burung langka, salinitas tambak meningkat, meningkatnya frekuensi dan intensitas banjir, sampah RT dan limbah industry menjadi penyebab abrasi, terganggunya obyek wisata pantai, tidak adanya tempat obyek penelitian, pendidikan dan pengembangan ilmu pengetahuan. Abrasi yang diakibatkan karena alam dan kerusakan tanaman mangrove, berdampak negatif secara sosial, ekonomi dan fungsional. Dari hasil kuisioner dampak fungsional responden menjawab 7 sebanyak $487 \quad(69,6 \%)$, menjawab 6 sebanyak $358 \quad(59,7 \%)$, menjawab 5 sebanyak $281 \quad(56,2 \%)$, menjawab 4 sebanyak 57 (14,2\%), menjawab 3 sebanyak 9 (3\%), menjawab 2 sebanyak $2(1 \%)$, menjawab 1 sebanyak 0 . Rata-rata jawaban responden 6,055.

\section{KESIMPULAN}

Konservasi akan bisa terealisasi dengan maksimal, apabila bangunan pemecah gelombang dibangun disepanjang pantai Tuban. Dimana tumpukan sedimen pasir yang terbentuk dibelakang pemecah gelombang bisa ditanami mangrove.

\section{DAFTAR PUSTAKA}

Anwar Jajanul, Damanik Sengli J, Hisyam Nazaruddin, Whitten Anthony J, 1984. Ekologi Ekosistem Sumatera. Gajah Mada University Press. Yogyakarta.

Bengen, D.G, 1999a. Ekosistem dan Sumberdaya Alam Pesisir. Pusat Kegiatan Sumberdaya Pesisir dan Lautan, Institut Pertanian Bogor. Bogor.

\begin{tabular}{cr} 
Pengenalan & \multicolumn{2}{c}{ dan Pedoman Teknis } \\
Ekosistem & Mangrover
\end{tabular}


Kegiatan Sumberdaya Pesisir dan Lautan, Institut Pertanian Bogor. Bogor.

Dahuri, 2004. Fungsi Ekologis dan Fungsi Sosial Ekonomi, Jakarta.

Harahap. N. 2009. Pengaruh ekosistem hutan mangrove terhadap produk perikanan tangkap (Studi Kasus Di Kabupaten Pasuruan, Jawa Timur). Jurnal Perikanan UGM. Yogyakarta. https://journal.ugm.ac.id/jfs/article/v iew/2989

Kariada, NTM. 2017. Peranan mangrove sebagai biofilter pencemaran air wilayah tambak bandeng tapak, semarang. Jurnal Manusia dan Lingkungan. UGM. Yogyakarta. https://journal.ugm.ac.id/JML/articl e/view/18543

N. Huda. 2008. Strategi kebijakan pengelolaan mangrove berkelanjutan di wilayah pesisir Kabupaten Tanjung Jabung Timur Jambi. Semarang. http://eprints.undip.ac.id/18579/

Nybakken, J. 1992, Biologi Laut Suatu Pendekatan Ekologi, Penerbit PT. Gramedia Jakarta.

Osgood, C.G.J Suci and Tannembaum, P.H, 1975. Semmantic Differensial Technique.

Singarimbun, Masri dan Sofian Efendi, 1989. Metode Penelitian Survey. LP3ES, Jakarta.

Sudjana, 1992. Metoda Statistika. Penerbit Tassito Bandung.
Teguh Suprapto, 2013. Mangrove Center Tuban, Balai Pengelolaan Daerah Aliran Sungai Solo. Surakarta.

Winarno, Y., Suryono, F.,Rouben G dan Andils. 1994. Aplikasi Sistem Informasi Geografi Untuk Pemetaan Informasi Pembangunan, Makalah Seminar Remote Sensing dan Geographic Information System, BPPT, Jakarta.

2009. Undang-Undang Republik Indonesia Nomor 32 tahun 2009 tentang, Pengelolaan Lingkungan Hidup. 